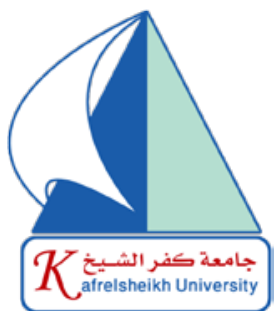

\author{
Kafrelsheikh Veterinary Medical Journal \\ (https://kvmj.journals.ekb.eg/)
}

CrossMark

Original Article

Received Aug 15, 2021

Accepted Sep 27, 2021

Published Oct 15, 2021

\title{
Impact of using some essential oils on sensory acceptability and Aeromonas hydrophila contamination of Nile tilapia fish fillet during refrigeration storage
}

\author{
Ghada A. K. Kirrella*1, Nader Y. Moustafa ${ }^{1}$, Dina M. Kishk ${ }^{2}$, Reda Abdallah ${ }^{1}$ \\ ${ }^{1}$ Department of Food Control, Faculty of Veterinary medicine, Kafrelsheikh University, Kafr El Sheikh, 33516, Egypt. \\ 2 M.V.Sc, Faculty of Veterinary medicine, Kafrelsheikh University. \\ *Correspondence: ghada.karala@vet.kfs.edu.eg
}

\begin{abstract}
Background/aim: Fresh fish is highly susceptible to spoilage with shorter shelf life especially during refrigeration storage. This study aimed to evaluate the effect of essential oils (EOs) of Thyme (Thymus vulgaris), Cinnamon (Cinnamomic zeylanicum), and Garlic (Allium sativum) with concentrations of 0.5 and $1 \%$ of each on sensory acceptability of Nile tilapia (Oreochromis niloticus) fish fillet during refrigeration storage at 4 $\pm 1^{\circ} \mathrm{C}$ and their ability to increase shelf life. The impact of these EOs on Aeromonas hydrophila contamination was also investigated.

Results: The results of the sensory evaluation showed that the overall acceptability of control samples significantly decreased as compared to EOs-treated samples. There was a higher significant $(\mathrm{P}<0.05)$ difference in the overall acceptability among different EOs, with the lowest scores in garlic EOs and the highest in $1 \%$ thyme oil. There was a positive effect on the shelf-life extension of fish fillet samples which differed according to type and concentration of EOs. The shelf life of samples treated with thyme oil was 12 days in the refrigerator and still fit for human consumption. In addition to reduction percentage of Aeromonas hydrophila count with significance difference $(\mathrm{P}<0.01)$ among different EOs showed better results for thyme oils compared to other EOs.

Conclusion: Using EOs reduced Aeromonas hydrophila growth without any adverse effect on the sensory attributes of the treated Nile tilapia fillets samples.
\end{abstract}

Keywords: Essential oils; Shelf life; Nile tilapia, sensory acceptability, Aeromonas hydrophila

\section{Introduction}

Fish is an excellent nutritive value food having high-quality protein and a large variety of vitamins and minerals (Pal et al., 2018). In contrast, due to its high moisture and nutrient content with a tendency for higher $\mathrm{pH}$, fish is highly susceptible to spoilage even during refrigerator storage with shorter shelf life ( $\mathrm{Li}$ et al., 2012). This spoilage is responsible for the initial loss of freshness affecting the sensory characters of fish. Fish act as a source of foodborne pathogens, including Aeromonas species that have been known as emerging foodborne pathogens of serious threat to a public health concern (Igbinosa et al., 2012). Sensory testing plays an important role in food quality evaluation where the ultimate criterion for eating quality of any food is a human response (Mlian et al., 2017).

Various studies reported that usage of chemical and/or synthetic food additives can lead to intoxications, degenerative diseases, and even cancer. This generates the need to look for alternative methods to extend shelf life and cover some antimicrobial properties. Recently, food preservation techniques have shown considerable interest in utilizing essential oils of natural substances extracted from medicinal and aromatic plants due to their ability to control the growth of pathogenic microorganisms (Aminzare et al.,2016).

Many trials attempt to reduce the incidence of Aeromonas species that essential oils can be added to fish flesh. It was noticed in comparison to several other mild preservation procedures like smoking, low dose irradiation, the addition of protective cultures, or high-pressure treatment that essential oils are inexpensive and uncomplicated methods of extending shelf-life of fish flesh (Mejlholm and Dalgaard, 2002). These natural preservatives could perfectly meet the increasing consumer demands for clean-label products that are fresh and free of chemical or synthetic additives therefore, using natural essential oils to preserve fish quality and extend shelf life are required (Hassoun and Çoban, 2017).

As consumers tend to adopt towards eating food containing no chemicals; essential oils come to fulfill part of the increasing demand for products of "green image" being obtained from natural sources (Holley and Patel, 2005). It was confirmed by in vitro experiments that Thyme, Cinnamon, garlic, and other spices inhibited the growth of both Gram-positive and Gram-negative food-borne pathogens (Guerino et al., 2019). They also prevent spoilage bacteria, yeast, and 
mold (Hoque et al., 2008). Using disk diffusion assay, the greatest zones of inhibition against Aeromonas species were obtained by many essential oils like Cinnamon, Oregano, Lemongrass, Thyme, and Garlic (Peyghan and Motamedi 2012; Starliper et al., 2015).

Essential oils can be added to fish flesh by dipping or spraying as one of the main methods of the natural preservatives as potential alternatives to the familiar preservatives (Khalafalla et al., (2015). The use of essential oils is a potentially novel approach to treat fish bacterial infections with a lower risk of bacterial resistance (Guerino et al., 2019). However, few studies are investigating the effect of these essential oils against fish bacteria as Aeromonas hydrophila and its impact on sensory acceptability for consumers. Therefore, this work aimed to determine the effect of some essential (Thyme, Garlic, and Cinnamon) oils on sensory characters of Nile tilapia (Oreochromis niloticus) fish fillet during refrigeration storage with minimum concentrations which still maintains the inhibitory effect on Aeromonas hydrophila count and has a positive effect on sensory characters trying to increase the shelf life.

\section{Materials and methods}

\subsection{Collection of samples}

A total number of 35 samples of Nile tilapia (Oreochromis niloticus) fish fillet with an average weight of $100 \mathrm{~g}$ were collected from fish markets in Kafr El-Sheikh city, Egypt. The samples were identified and packaged separately in a sterile plastic bag under aseptic conditions. The samples were transferred directly with a minimum of delay to the laboratory Food control department, Faculty of Veterinary Medicine, Kafrelsheikh University to apply the protocol of treatment. For purpose of in vitro examination of antimicrobial activity of essential oils on the fish fillet, standardized Aeromonas hydrophila strain $\left(5 \times 10^{7} \mathrm{CFU} / \mathrm{g}\right)$ was obtained from Food Analysis Center, Faculty of Veterinary Medicine, Benha University, Egypt.

\subsection{Preparation of fish samples}

Essential oils of Thyme (Thymus vulgaris), Garlic (Allium sativum), and Cinnamon (Cinnamomum zeylanicum) with concentrations of 0.5 and $1 \%$, for each were purchased from the oil extraction unit, National Research Center, Egypt.

\subsection{Preparation of treated samples}

The samples were divided into 7 groups; each group contain 5 samples with fixed weight (100 g/fillet) and all samples were inoculated with Aeromonas hydrophila strain $\left(5 \times 10^{7} \mathrm{CFU} / \mathrm{g}\right)$. This was followed by dipping the sample in treated extract for 10 minutes. (Khalafalla et al., 2015). The 7 groups were divided as follow: The $1^{\text {st }}$ group (untreated control) group; the $2^{\text {nd }}$ group dipped in Thyme extract $0.5 \%$; the $3^{\text {rd }}$ group dipped in Thyme extract $1 \%$; the $4^{\text {th }}$ group dipped in Garlic extract $0.5 \%$; the $5^{\text {th }}$ group dipped in Garlic extract $1 \%$; the $6^{\text {th }}$ group dipped in Cinnamon extract $0.5 \%$; and the $7^{\text {th }}$ group dipped in Cinnamon extract $1 \%$.

\subsection{Packaging and storage}

Treated and untreated fish fillets were labeled and aerobically packaged inside fiber dishes, then stored at $4 \pm 1{ }^{\circ} \mathrm{C}$ inside the refrigerator. The treated groups were subjected to sensory evaluation and Aeromonas counts at day zero (within $2 \mathrm{~h}$ after treatment) then periodically every three days until decomposition.

\subsection{Sensory evaluation}

The sensory assessment was performed on the raw fish fillet using the scoring test Fan et al., (2008). Sensory evaluation was based on a five-point scale to determine: odor (5, extremely desirable; 1 , extremely unacceptable); color discoloration (5, no discoloration; 1 , extreme discoloration); texture (5, firm; 1 , very soft); and general appearance (5, extremely desirable; 1 , extremely unacceptable) of the samples. When the sensory attributes declined below 4.0, the samples were rejected.

\subsection{Aeromonas hydrophila strain inoculation}

Aeromonas hydrophila strain was subculture on Brain Heart Infusion (BHI) broth and incubated for 24 hours at $37^{\circ} \mathrm{C}$. The cells were harvested by centrifugation $(3000 \times \mathrm{g}, 15 \mathrm{~min})$, washed twice and resuspended with saline $(\mathrm{NaCl}, 0.85 \%$, w/v) (Tassou et al.,1995). For inoculation of the Orechromis niloticus fillets, $1 \mathrm{ml}$ of the dense suspension $5 \times 10^{7} / \mathrm{g}$ for Aeromonas hydrophila was employed.

\subsection{Aeromonas hydrophila count}

One $\mathrm{ml}$ of homogenized sample was aseptically transferred into the surface of specific media of Aeromonas species (Aeromonas Agar Media, Lab M) and then was spread by a sterile glass spreader. Inoculated plates were incubated at $37^{\circ} \mathrm{C}$ for $18-24$ hours. All confirmed colonies (translucent, pale green colonies $0.5-3.0 \mathrm{~mm}$ diameter) were counted as Aeromonas according to this formula: Aeromonas count $/ g=$ No. of colonies $\times$ dilution factors $\times 10$.

\subsection{Statistical analysis}

The evaluation and interpretation of obtained results were carried out using one-way ANOVA and Chi-squared test to detect the significant difference in the obtained results.

\section{Results}

\subsection{Sensory evaluation}

As shown in table (1), the mean values of essential oils effects on odor, color, texture, and general appearance ( 5 points, for each) of Nile tilapia fillets samples which concluded by the mean values of overall acceptability (20 points) on sensory acceptability provided by panelists of control, thyme, garlic and cinnamon oils ( 0.5 and $1 \%$ ) group samples at different refrigerator storage time. Where, the mean values of overall acceptability of control samples were $18.51 \pm 0.51$ and $9.13 \pm 2.13$ after the first 2 hours and the $3^{\text {rd }}$ day, respectively and the mean values of thyme $0.5 \%$ group samples were $18.18 \pm 0.18,15.54 \pm 2.15,13.06 \pm 1.33$, and $9.48 \pm 1.44$ after the first 2 hours, $3^{\text {rd }}, 6^{\text {th }}$ and $9^{\text {th }}$ day, respectively. While the mean values of thyme $1 \%$ group samples were $17.6 \pm 2.17,15.28 \pm 4.15$, $13.54 \pm 0.40,11.36 \pm 1.33$, and $7.94 \pm 1.77$ after the first 2 hours, $3^{\text {rd }}$, $6^{\text {th }}, 9^{\text {th, }}$ and the $12^{\text {th }}$ day, respectively.

Moreover, the mean values of garlic $0.5 \%$ group samples were $15.5 \pm 1.55,11.8 \pm 3.11,8 \pm 1.80$ after the first 2 hours, $3^{\text {rd }}$ and $6^{\text {th }}$ day, respectively. As well as garlic $1 \%$ group samples were $13.95 \pm 1.34$, $10.65 \pm 5.16,7.9 \pm 1.77$ after the first 2 hours, $3^{\text {rd }}$ and $6^{\text {th }}$ day, respectively. In addition to the mean values of cinnamon $0.5 \%$ group samples were $18.65 \pm 1.65,14 \pm 4.11$, and $10.45 \pm 1.44$ after the first 2 hours, $3^{\text {rd }}$ and $6^{\text {th }}$ day, respectively. While cinnamon $1 \%$ group samples were $18.04 \pm 1.64,14.83 \pm 3.18,11.9 \pm 1.89,7.4 \pm 1.17$ after the first 2 hours, $3^{\text {rd }}, 6^{\text {th }}$ and $9^{\text {th }}$ day, respectively.

These results indicated that there was a high significance 
difference of mean values of overall acceptability of samples $(\mathrm{P}<$ 0.05 ) among different essential oils extract. Whereas it was noticed after the first 2 hours of applying the treatment in thyme and cinnamon (0.5 and $1 \%$ ) group samples were very good, while low scores were given to garlic (0.5 and $1 \%)$ group samples.
Meanwhile, the mean values of overall acceptability of samples decreased rapidly in control samples. On the other hand, sensory acceptability takes time to decrease in treated samples according to the type and concentration of essential oil.

Table 1. Mean values of essential oils on sensory acceptability of fish fillets $(n=5)$.

\begin{tabular}{|c|c|c|c|c|c|c|c|}
\hline \multirow{2}{*}{$\begin{array}{c}\text { Sensory } \\
\text { attributes }\end{array}$} & \multirow[t]{2}{*}{ Samples } & \multicolumn{6}{|c|}{ Storage periods } \\
\hline & & $\begin{array}{c}\text { Zero day } \\
\text { After 2-hour } \\
\text { treatment }\end{array}$ & $3^{\text {rd }}$ day & $6^{\text {th }}$ day & $9^{\text {th }}$ day & $12^{\text {th }}$ day & $15^{\text {th }}$ day \\
\hline Odor & Control & $4.9 \pm 0.9^{a}$ & $2.6 \pm 0.20^{\mathrm{e}}$ & $0.12 \pm 02^{\mathrm{e}}$ & - & - & - \\
\hline \multirow[t]{6}{*}{ (5 points) } & Thyme $0.5 \%$ & $4.5 \pm 0.5^{b}$ & $4.2 \pm 0.4^{\mathrm{a}}$ & $3.5 \pm 0.30^{\mathrm{a}}$ & $2.6 \pm 0.12^{\mathrm{b}}$ & $1.28 \pm 0.11^{\mathrm{b}}$ & - \\
\hline & Thyme 1\% & $4.0 \pm 0.2^{c}$ & $3.6 \pm 0.3^{c}$ & $3.2 \pm 0.30^{\mathrm{b}}$ & $2.8 \pm 0.18^{\mathrm{a}}$ & $2.1 \pm 0.11^{\mathrm{a}}$ & $1.15 \pm 0.11^{\mathrm{a}}$ \\
\hline & Garlic $0.5 \%$ & $3.3 \pm 0.3^{d}$ & $2.9 \pm 0.3^{d}$ & $2.0 \pm 0.10^{c}$ & $0.62 \pm 0.10^{\mathrm{e}}$ & - & - \\
\hline & Garlic 1\% & $2.2 \pm 0.20^{\mathrm{e}}$ & $1.8 \pm 0.3^{f}$ & $1.2 \pm 0.11^{\mathrm{d}}$ & $0.36 \pm 0.10^{f}$ & - & - \\
\hline & Cinnamon $0.5 \%$ & $4.95 \pm 0.20^{\mathrm{a}}$ & $4.0 \pm 0.20^{\mathrm{b}}$ & $3.3 \pm 0.13^{b}$ & $1.15 \pm 0.10^{\mathrm{d}}$ & - & - \\
\hline & Cinnamon $1 \%$ & $4.0 \pm 0.12^{\mathrm{c}}$ & $3.55 \pm 0.50^{c}$ & $3.2 \pm .12^{b}$ & $2.2 \pm 0.12^{\mathrm{c}}$ & $1.22 \pm 0.11^{\mathrm{c}}$ & - \\
\hline Color & Control & $4.75 \pm 0.5^{b}$ & $2.45 \pm 0.5^{f}$ & $0.41 \pm 0.1^{\mathrm{f}}$ & - & - & - \\
\hline \multirow[t]{6}{*}{ (5 points) } & Thyme $0.5 \%$ & $4.6 \pm 0.6^{b}$ & $3.6 \pm 0.3^{b}$ & $3.0 \pm 0.10^{\mathrm{b}}$ & $2.4 \pm 0.10^{\mathrm{b}}$ & $0.78 \pm 0.1^{\mathrm{b}}$ & - \\
\hline & Thyme 1\% & $4.7 \pm 0.7^{b}$ & $3.9 \pm 0.3^{\mathrm{a}}$ & $3.54 \pm 0.4^{\mathrm{a}}$ & $2.86 \pm 0.6^{a}$ & $2.3 \pm 0.10^{\mathrm{a}}$ & $0.74 \pm 0.10^{\mathrm{a}}$ \\
\hline & Garlic $0.5 \%$ & $4.4 \pm 0.6^{c}$ & $3.0 \pm 0.2^{\mathrm{e}}$ & $2.1 \pm 0.2^{\mathrm{e}}$ & $0.7 \pm 0.10^{\mathrm{d}}$ & - & - \\
\hline & Garlic 1\% & $4.35 \pm 0.4^{\mathrm{c}}$ & $3.35 \pm 0.3^{c}$ & $2.4 \pm 0.10^{\mathrm{d}}$ & $1.13 \pm 0.1^{\mathrm{c}}$ & - & - \\
\hline & Cinnamon $0.5 \%$ & $4.5 \pm .5^{c}$ & $3.1 \pm 0.3^{d}$ & $2.35 \pm 0.30^{\mathrm{d}}$ & $0.6 \pm 0.10^{\mathrm{d}}$ & - & - \\
\hline & Cinnamon 1 & $4.82 \pm 0.2^{\mathrm{a}}$ & $3.84 \pm 0.3^{\mathrm{a}}$ & $2.88 \pm 0.2^{\mathrm{c}}$ & $1.8 \pm 0.10^{c}$ & $0.3 \pm 0.01^{\mathrm{c}}$ & - \\
\hline \multirow{8}{*}{$\begin{array}{l}\text { Texture } \\
\text { (5 points) }\end{array}$} & Control & $4.36 \pm 0.36^{b}$ & $2.26 \pm 0.2^{\mathrm{c}}$ & $0.34 \pm 0.03^{\mathrm{d}}$ & - & - & - \\
\hline & Thyme $0.5 \%$ & $472+070^{a}$ & $4.0 \pm 0.20^{\mathrm{a}}$ & $3.2 \pm 0.20^{\mathrm{a}}$ & $2.2 \pm 0.10^{\mathrm{a}}$ & $0.45 \pm 0.20^{\mathrm{b}}$ & - \\
\hline & Thyme 1\% & $4.72 \pm 0.10^{a}$ & $3.98 \pm 0.30^{\mathrm{a}}$ & $3.5 \pm 0.30^{\mathrm{a}}$ & $3.0 \pm 0.21^{\mathrm{a}}$ & $1.54 \pm 0.15^{\mathrm{a}}$ & $0.68 \pm 0.11^{\mathrm{a}}$ \\
\hline & Garlic $0.5 \%$ & $4.6 \pm 0.40^{\mathrm{a}}$ & $3.2 \pm 0.20^{\mathrm{b}}$ & $2.0 \pm 0.10^{c}$ & $0.54 \pm 0.21^{\mathrm{c}}$ & - & - \\
\hline & Garlic 1\% & $4.38 \pm 0.40^{\mathrm{b}}$ & $3.1 \pm 0.30^{\mathrm{b}}$ & $2.7 \pm 0.22^{\mathrm{b}}$ & $0.57 \pm 0.15^{c}$ & - & - \\
\hline & Cinnamon $0.5 \%$ & $4.2 \pm 0.22^{\mathrm{b}}$ & $3.7 \pm 0.30^{\mathrm{a}}$ & $2.6 \pm 0.21^{\mathrm{b}}$ & $0.31 \pm 0.11^{\mathrm{c}}$ & - & - \\
\hline & Cinnamon 1 & $4.8 \pm 0.30^{\mathrm{a}}$ & $3.7 \pm 0.12^{\mathrm{a}}$ & $2.9 \pm 0.20^{\mathrm{b}}$ & $1.8 \pm 0.11^{\mathrm{b}}$ & $0.37 \pm 0.10^{\mathrm{b}}$ & - \\
\hline & & $4.7 \pm 0.23^{\mathrm{a}}$ & & & & & \\
\hline \multirow{7}{*}{$\begin{array}{c}\text { General } \\
\text { appearance } \\
\text { (5 points) }\end{array}$} & Control & $4.5 \pm 0.4^{\mathrm{a}}$ & $1.82 \pm 21^{\mathrm{c}}$ & $0.5 \pm 0.02^{\mathrm{e}}$ & - & - & - \\
\hline & Thyme $0.5 \%$ & $4.36 \pm 0.30^{\mathrm{a}}$ & $3.74 \pm 14^{\mathrm{a}}$ & $3.36 \pm 0.03^{\mathrm{a}}$ & $2.28 \pm 0.12^{b}$ & $0.62 \pm 0.20^{\mathrm{b}}$ & - \\
\hline & Thyme $1 \%$ & $4.3 \pm 0.30^{\mathrm{a}}$ & $3.8 \pm 31^{\mathrm{a}}$ & $3.3 \pm 0.30^{\mathrm{a}}$ & $2.7 \pm 0.12^{\mathrm{a}}$ & $2.0 \pm 0.10^{\mathrm{a}}$ & $0.55 \pm 0.11^{\mathrm{a}}$ \\
\hline & Garlic 0.5\% & $3.42 \pm 0.21^{\mathrm{a}}$ & $2.7 \pm 21^{\mathrm{b}}$ & $1.9 \pm 0.11^{\mathrm{d}}$ & $0.62 \pm 0.12^{\mathrm{d}}$ & - & - \\
\hline & Garlic 1\% & $3.2 \pm 22^{b}$ & $2.4 \pm 21^{\mathrm{b}}$ & $1.6 \pm 0.11^{\mathrm{d}}$ & $0.3 \pm 0.13^{d}$ & - & - \\
\hline & Cinnamon $0.5 \%$ & $4.4 \pm 21^{\mathrm{a}}$ & $3.2 \pm 21^{\mathrm{a}}$ & $2.2 \pm 0.12^{\mathrm{c}}$ & $0.44 \pm 0.14^{\mathrm{d}}$ & - & - \\
\hline & Cinnamon 1 & $4.52 \pm 21^{\mathrm{a}}$ & $3.74 \pm 17^{a}$ & $2.92 \pm 0.12^{\mathrm{b}}$ & $1.6 \pm 0.11^{\mathrm{c}}$ & $0.54 \pm 0.11^{b}$ & - \\
\hline \multirow{7}{*}{$\begin{array}{c}\text { Overall } \\
\text { acceptability } \\
\text { (20 Points) }\end{array}$} & Control & $18.51 \pm 0.51^{\mathrm{a}}$ & $9.13 \pm 2.13^{\mathrm{d}}$ & $1.37 \pm 0.2^{f}$ & - & - & - \\
\hline & Thyme $0.5 \%$ & $18.18 \pm 0.18^{a}$ & $15.54 \pm 2.15^{\mathrm{a}}$ & $13.06 \pm 1.33^{a}$ & $9.48 \pm 1.44^{\mathrm{b}}$ & $3.13 \pm 1.33^{b}$ & - \\
\hline & Thyme 1\% & $17.6 \pm 2.17^{b}$ & $15.28 \pm 4.15^{\mathrm{a}}$ & $13.54 \pm 0.40^{\mathrm{a}}$ & $11.36 \pm 1.33^{a}$ & $7.94 \pm 1.77^{a}$ & $3.12 \pm 1.14^{\mathrm{a}}$ \\
\hline & Garlic $0.5 \%$ & $15.5 \pm 1.55^{c}$ & $11.8 \pm 3.11^{\mathrm{b}}$ & $8.0 \pm 1.80^{\mathrm{e}}$ & $2.48 \pm 1.44^{\mathrm{d}}$ & - & - \\
\hline & Garlic 1\% & $13.95 \pm 1.34^{\mathrm{d}}$ & $10.65 \pm 5.16^{\mathrm{c}}$ & $7.9 \pm 1.77^{\mathrm{d}}$ & $2.36 \pm 1.38^{d}$ & - & - \\
\hline & Cinnamon $0.5 \%$ & $18.65 \pm 1.65^{\mathrm{a}}$ & $14.0 \pm 4.11^{\mathrm{b}}$ & $10.45 \pm 1.44^{\mathrm{c}}$ & $2.5 \pm 0.55^{d}$ & - & - \\
\hline & Cinnamon 1 & $18.04 \pm 1.64^{\mathrm{a}}$ & $14.83 \pm 3.18^{b}$ & $11.9 \pm 1.89^{\mathrm{b}}$ & $7.4 \pm 1.17^{c}$ & $2.43 \pm 1.43^{c}$ & - \\
\hline
\end{tabular}

Mean values within the same column of different letters are significantly different at $(\mathrm{P}<0.05)$

\subsection{Impact of essential oils on Aeromonas hydrophila}

Table (2) revealed the mean values of essential oils against Aeromonas hydrophila counts of fish fillets samples which were experimentally inoculated with Aeromonas hydrophila strain by intensity $5 \times 10^{7} \mathrm{CFU} / \mathrm{g}$ at different refrigerator storage times. Whereas, the initial counts in control samples increased gradually during the refrigerator storage time starting with a mean value of $7.71 \times 10^{7} \pm 0.71 \times 10^{7} \mathrm{CFU} / \mathrm{g}$ after the first 2 hours. There was significant difference $(\mathrm{P}<0.01)$ between essential oils with high significant difference of thyme $1 \%$. While cinnamon $0.5 \%$ was the least essential oil affect Aeromonas hydrophila count. Finally, as illustrated in Table (3) the reduction percentage of essential oils against Aeromonas hydrophila counts was calculated. Whereas it was. Whereas it was reported that the most reduction percentage was to thyme oil $1 \%$ which extend up to the $12^{\text {th }}$ day of refrigerator storage time followed by Cinnamon $1 \%$ and Thyme $0.5 \%$. Despite cinnamon $0.5 \%$ concentration did not present any reduction against Aeromonas hydrophila counts at the $9^{\text {th }}$ and $12^{\text {th }}$ day of storage. However, there was a low reduction percentage on the $3^{\text {th }}$ and $6^{\text {th }}$ day. As well as garlic 1 and $0.5 \%$ concentration did not present any reduction against Aeromonas hydrophila counts at the $9^{\text {th }}$ and $12^{\text {th }}$ day of storage but, nearly similar in reduction percentage as thyme and cinnamon. 
Table2. Mean values of essential oils on Aeromonas hydrophila counts of fish fillets $(n=5)$.

\begin{tabular}{|c|c|c|c|c|c|c|c|}
\hline Time & Control & $\begin{array}{c}\text { Thyme } \\
0.5 \%\end{array}$ & $\begin{array}{c}\text { Thyme } \\
1 \%\end{array}$ & $\begin{array}{c}\text { Garlic } \\
0.5 \%\end{array}$ & $\begin{array}{c}\text { Garlic } \\
1 \%\end{array}$ & $\begin{array}{c}\text { Cinnamon } \\
0.5 \%\end{array}$ & $\begin{array}{c}\text { Cinnamon } \\
1 \%\end{array}$ \\
\hline $\begin{array}{l}\text { Zero day } \\
\text { (after } 2 \text { h) }\end{array}$ & $\begin{array}{c}7.71 \times 10^{7} \\
\pm \\
0.71 \times 10^{7 \mathrm{a}}\end{array}$ & $\begin{array}{c}1.19 \times 10^{7} \\
\pm \\
0.21 \times 10^{7 e}\end{array}$ & $\begin{array}{c}1.43 \times 10^{6} \\
\pm \\
0.41 \times 10^{7 f}\end{array}$ & $\begin{array}{c}4.00 \times 10^{7} \\
\pm \\
0.44 \times 10^{7 \mathrm{c}}\end{array}$ & $\begin{array}{c}2.77 \times 10^{7} \\
\pm \\
0.22 \times 10^{7 d}\end{array}$ & $\begin{array}{c}6.40 \times 10^{7} \\
\pm \\
0.44 \times 10^{7 b}\end{array}$ & $\begin{array}{c}2.60 \times 10^{6} \\
\pm \\
0.57 \times 10^{7 \mathrm{e}}\end{array}$ \\
\hline $3^{\text {rd }}$ day & $\begin{array}{c}1.49 \times 10^{9} \\
\pm \\
0.41 \times 10^{7 a}\end{array}$ & $\begin{array}{c}1.20 \times 10^{8} \\
\pm \\
0.75 \times 10^{7 \mathrm{c}}\end{array}$ & $\begin{array}{c}2.17 \times 10^{7} \\
\pm \\
0.27 \times 10^{7 f}\end{array}$ & $\begin{array}{c}5.82 \times 10^{7} \\
\pm \\
0.27 \times 10^{7 d}\end{array}$ & $\begin{array}{c}3.40 \times 10^{7} \\
\pm \\
0.37 \times 10^{7 d}\end{array}$ & $\begin{array}{c}7.81 \times 10^{8} \\
\pm \\
0.77 \times 10^{7 b}\end{array}$ & $\begin{array}{c}2.87 \times 10^{7} \\
\pm \\
0.81 \times 10^{7 \mathrm{e}}\end{array}$ \\
\hline $6^{\text {th }}$ day & Spoiled ${ }^{a}$ & $\begin{array}{c}1.26 \times 10^{8} \\
\pm \\
0.27 \times 10^{7 \mathrm{c}}\end{array}$ & $\begin{array}{c}1.09 \times 10^{8} \\
\pm \\
0.29 \times 10^{7 f}\end{array}$ & $\begin{array}{c}1.38 \times 10^{8} \\
\pm \\
0.33 \times 10^{7 \mathrm{e}}\end{array}$ & $\begin{array}{c}2.37 \times 10^{8} \\
\pm \\
0.37 \times 10^{7 d}\end{array}$ & $\begin{array}{c}9.24 \times 10^{8} \\
\pm \\
0.27 \times 10^{7 b}\end{array}$ & $\begin{array}{c}1.00 \times 10^{8} \\
\pm \\
0.28 \times 10^{7 g}\end{array}$ \\
\hline $9^{\text {th }}$ day & & $\begin{array}{c}1.45 \times 10^{8} \\
\pm \\
0.47 \times 10^{7 \mathrm{~d}}\end{array}$ & $\begin{array}{c}1.61 \times 10^{8} \\
\pm \\
0.61 \times 10^{7 \mathrm{c}}\end{array}$ & Spoiled ${ }^{\mathrm{a}}$ & Spoiled a & Spoiled ${ }^{\mathrm{a}}$ & $\begin{array}{c}6.02 \times 10^{8} \\
\pm \\
0.67 \times 10^{7 b}\end{array}$ \\
\hline $12^{\text {th }}$ day & & Spoiled ${ }^{a}$ & $\begin{array}{c}1.87 \times 10^{8} \\
\pm \\
0.87 \times 10^{7 b} \\
\text { Spoiled }^{\mathrm{a}}\end{array}$ & & & & Spoiled ${ }^{\mathrm{a}}$ \\
\hline
\end{tabular}

Mean values within the same row of different letters are significantly different at $(\mathrm{P}<0.01)$.

Table 3. Reduction percentage of essential oils on Aeromonas hydrophila count.

\begin{tabular}{|c|c|c|c|c|c|c|}
\hline Time & $\begin{array}{l}\text { Control/ } \\
\text { Thyme } 0.5 \%\end{array}$ & $\begin{array}{l}\text { Control/ Thyme } \\
1 \%\end{array}$ & $\begin{array}{l}\text { Control/ Garlic } \\
0.5 \%\end{array}$ & $\begin{array}{l}\text { Control/ Garlic } \\
1 \%\end{array}$ & $\begin{array}{l}\text { Control/ } \\
\text { Cinnamon } \\
0.5 \%\end{array}$ & $\begin{array}{l}\text { Control/ } \\
\text { Cinnamon } \\
1 \%\end{array}$ \\
\hline Zero day (after 2 h) & $84.6 \%$ & $98.1 \%$ & $48.1 \%$ & $64 \%$ & $17 \%$ & $96.6 \%$ \\
\hline $3^{\text {rd }}$ day & $91.9 \%$ & $98.5 \%$ & $96 \%$ & $97.7 \%$ & $47.6 \%$ & $98 \%$ \\
\hline $6^{\text {th }}$ day & $91.5 \%$ & $92.7 \%$ & $90.7 \%$ & $84 \%$ & $38 \%$ & $93 \%$ \\
\hline $9^{\text {th }}$ day & $90 \%$ & $89 \%$ & - & - & - & $60 \%$ \\
\hline $12^{\text {th }}$ day & - & $87.4 \%$ & - & - & - & - \\
\hline
\end{tabular}

Chi2 $=25.30 * *$

$* *=$ Significant at $(\mathrm{P}<0.01)$

\section{Discussion}

Sensory evaluation is the most popular way of assessing the freshness of fish. It is fast, simple, and provides immediate quality information (Reineccius, 1990). The most effective essential oils on overall acceptability was thyme with a concentration of $1 \%$ than $0.5 \%$ whereas the shelf life of samples extended till the $9^{\text {th }}$ day with a concentration of $0.5 \%$ and the $12^{\text {th }}$ day with a concentration of $1 \%$. This may be attributed to the effective material thymol present in it which is characterized by strong flavor, pleasant aromatic odor, and strong antiseptic properties. For that reason, thyme essential oil is considered a flavoring agent in the food industry (Anžlovar et al., 2014). In addition, the cinnamon essential oil was used widely in coloration and deodorant in the food industry because it contains the cinnamaldehyde compound. That is why cinnamon maintains the sensory attributes better than garlic essential oil. While the garlic is characterized by the remarkable sulfur-containing compound present in it which gives the samples its distinctive smell and yellow discoloration. So, garlic can't maintain the sensory attributes for a long time compared to thyme and cinnamon essential oils (Peter, 2012). The obtained results agreed with Khalafalla et al. (2015) who concluded that using thyme essential oil with a concentration of $0.5 \%$ maintained the sensory parameters of the fish fillets samples until the $18^{\text {th }}$ during refrigerated temperature and Zhang et al. (2017) who recorded that cinnamon essential oil with a concentration of $0.1 \%$ extended the shelf-life of vacuum-packaged common carp fillets by about 2 days.

Aeromonas species aren't found only in fresh fish, but also, they grow in refrigerated storage. For that, there were many attempts to reduce the incidence of Aeromonas species in fish samples during refrigerated storage (Hoel et al., 2019). Our results indicated that there was a highly significant difference in the mean values of Aeromonas counts $(\mathrm{P}<0.01)$ among different essential oils. Whereas thyme $1 \%$ gave the better result in reducing the growth of Aeromonas species until the $12^{\text {th }}$ day of the storage time in comparison to other treated samples. Thyme contained three compounds (linalool, thymol, and carvacrol) which showed the highest antimicrobial effects against Gram-negative and Gram-positive bacteria (Mahboubi et al., 2017). While thyme $0.5 \%$ needed more time to reduce the growth of 
Aeromonas species and this may be attributed to the high concentration of $1 \%$ compared to $0.5 \%$. Cinnamon $1 \%$ showed a high reduction against Aeromonas species due to the action of cinnamaldehyde which possesses the highest antimicrobial against both Gram-negative and gram-positive bacteria. While cinnamon $0.5 \%$ can't achieve the satisfactory antibacterial against Aeromonas species (Zhang et al., 2017). It was observed that garlic with both concentrations ( 0.5 and $1 \%$ ) has a high reduction against Aeromonas species due to its complex chemical composition such as diallyl mono-, di- and tri-sulfide, which possess the high biological potential as an antimicrobial effect. On the other hand, it was noted that changes in sensory attributes and couldn't be able to extend the shelf life for a long time in comparison to thyme and cinnamon. The obtained results agreed with Khalafalla et al. (2015) who found that the dipping of Nile tilapia fillets into thyme extract $(0.5 \%)$ before refrigeration can control the number of Aeromonas species found in the treated fish samples by retaining the quality attributes.

\section{Conclusion}

The addition of essential oils with antimicrobial effects, maintain fish quality and extend the shelf life of fish under refrigerator storage at $4 \pm 1^{\circ} \mathrm{C}$. The storage time differs according to the type and concentration of essential oil. Dipping fish fillets into thyme with 0.5 and $1 \%$ concentration for 10 minutes before refrigeration can retain the quality attributes and extend the shelf life for about 6 and 9 days, respectively more than control samples during refrigerator storage at $4 \pm 1^{\circ} \mathrm{C}$. Moreover, it reduced Aeromonas hydrophila growth without any adverse effect on the sensory attributes of the treated fillets samples.

\section{Conflict of interest}

The authors declare that they have no conflict of interest.

\section{Research Ethics Committee Permission}

This study was approved by the local Ethics and guides of the Faculty of Veterinary Medicine, Kafrelsheikh University University Egypt.

\section{Authors' contribution}

Ghada A. K. Kirrella and Nader Y. Moustafa designed and conducted the study. Dina M. Kishk performed the practical study. All authors collected and analyzed the data. Ghada A. K. Kirrella drafted the manuscript. The final version of manuscript was revised and approved by Ghada A. K. Kirrella and Reda Abdallah.

\section{References}

Aminzare M, Hashemi M, Hassanzad Azar H, Hejazi J. 2016.The Use of Herbal Extracts and Essential Oils as a Potential Antimicrobial in Meat and Meat Products; A review. Journal of Human, Environment, and Health Promotion.;1(2):63-74.

Anžlovar, S., Baričevič, D., Ambrožič Avguštin, J., \& Dolenc Koce, J. 2014. Essential oil of common thyme as a natural antimicrobial food additive. Food Technology and Biotechnology, 52(2), 263268.

Fan, W., Chi, Y., \& Zhang, S. 2008. The use of a tea polyphenol dip to extend the shelf life of silver carp (Hypophthalmicthys molitrix) during storage in ice. Food chemistry, 108(1), 148-153.

Guerino, B.J., CarineF.S., Matheus, D.B., Sharine, N.D., Caiane, T., Bibiana P.S., Rosa, H.V. M., and Agueda, P.C.V. 2019. Plant essential oils against bacteria isolated from fish: an in vitro screening and in vivo efficiency of Lippia Origanoides. Microbiology. Cienc.Rural. 49(6).

Hassoun, A., \& Çoban, Ö. E. 2017. Essential oils for antimicrobial and antioxidant applications in fish and other seafood products. Trends in Food Science \& Technology, 68, 26-36.

Hoel, S., Vadstein, O., \& Jakobsen, A. N. 2019. The significance of mesophilic Aeromonas spp. in minimally processed ready-to-eat seafood. Microorganisms, 7(3), 91.

Holly, R.A., Patel, D. 2005.Improvement in shelf life and safety of perishable foods by plant essential oils and smoke antimicrobials. Food microbiol. Journal 22: 273-92.

Hoque, M. M., Bari, M. L., Juneja, V. K., \& Kawamoto, S. 2008. Antimicrobial activity of cloves and cinnamon extracts against food borne pathogens and spoilage bacteria and inactivation of Listeria monocytogenes in ground chicken meat with their essential oils. Food Research Institute, 72, 9-21.

Igbinosa, I. H., Igumbor, E. U., Aghdasi, F., Tom, M., \& Okoh, A. I. 2012. Emerging Aeromonas species infections and their significance in public health. The Scientific World Journal, 2012.

Khalafalla, F. A., Ali, F. H., \& Hassan, A. R. H. 2015. Quality improvement and shelf-life extension of refrigerated Nile tilapia (Oreochromis niloticus) fillets using natural herbs. Beni-Suef University Journal of Basic and Applied Sciences, 4(1), 33-40.

Li, T., Li, J., Hu, W., Zhang, X., Li, X. and Zhao, J. 2012. Shelf life extension of crucian carp (Carassius auratus) using natural preservatives during chilled storage. Food chemistry Journal, 135(1), 140-145.

Mahboubi, M., Heidarytabar, R., Mahdizadeh, E., \& Hosseini, H. 2017. Antimicrobial activity and chemical composition of Thymus species and Zataria multiflora essential oils. Agriculture and Natural Resources, 51(5), 395-401.

Mejlholm, O., \& Dalgaard, P. 2002. Antimicrobial effect of essential oils on the seafood spoilage micro-organism Photobacterium phosphoreum in liquid media and fish products. Letters in applied microbiology, 34(1), 27-31.

Mlian K.S., Hafiz R.S., and Muhammad N. 2017. Sensory evaluation of consumers acceptability. Hand Book of Food Science and Technology, pp 362-386.

Pal, J., Shukla, B. N., Maurya, A. K., Verma, H. O., Pandey, G., \& Amitha, A. 2018. A review on role of fish in human nutrition with special emphasis to essential fatty acid. International Journal of Fisheries and Aquatic Studies, 6(2), 427-430.

Peter, K. V. (Ed.). 2012. Handbook of herbs and spices. Vol.1 $2^{\text {nd }}$ Edn. Elsevier; pp 591-609.

Peyghan, R., \& Motamedi, H. 2012. In-vitro study of inhibitory effect of garlic extract on Aeromonas sobria. Iranian Journal of Veterinary Medicine, 6(4), 213-217.

Reineccius, G. 1990. Off-flavors in foods. Crit Rev Food Science Nutrition; 29:381e402.

Starliper, C. E., Ketola, H. G., Noyes, A. D., Schill, W. B., Henson, F. G., Chalupnicki, M. A., \& Dittman, D. E. 2015. An investigation of the bactericidal activity of selected essential oils to Aeromonas spp. Journal of advanced research, 6(1), 89-97.

Tassou, C., E. Drosinos and G. Nychas, 1995. Effects of essential oil from mint (Mentha piperita) on Salmonella enteritidis and Listeria monocytogenes in model food systems at $4^{\circ} \mathrm{C}$ and $10^{\circ} \mathrm{C}$. J. Appl. Bacteriol., 78: 593-600.

Zhang, Y., Li, D., Lv, J., Li, Q., Kong, C., \& Luo, Y. 2017. Effect of cinnamon essential oil on bacterial diversity and shelf-life in vacuumpackaged common carp (Cyprinus carpio) during refrigerated storage. International journal of food microbiology, 249, 1-8. 